'BALAMORY REVISITED': AN EVALUATION OF THE SCREEN

TOURISM DESTINATION-TOURIST NEXUS

Tourism Management 30 (2): 194-207 (2009)

Dr Joanne Connell *

Department of Marketing

University of Stirling

Stirling

FK9 4LA

Scotland

Email: j.j.connell@stir.ac.uk

Tel: $\quad+44(0) 1786466452$

Dr Denny Meyer

Faculty of Life and Social Sciences

Hawthorn Campus

Swinburne University of Technology

Melbourne

Australia

*corresponding author 


\section{BALAMORY REVISITED: AN EVALUATION OF THE SCREEN TOURISM DESTINATION-TOURIST NEXUS}

\section{INTRODUCTION}

The impact of screen tourism is evident in destinations world-wide and a growing body of research seeks to estimate, validate and evaluate its effects. In the UK alone, screen tourism is estimated to be worth about $£ 1.6$ billion, prompting about one in every five overseas visits to the country (Oxford Economic Forecasting 2005). While the emergence and growth of the phenomenon has generated investigations into place awareness, effects on visitor numbers and the consequences of visits to film-related destinations (see Beeton 2005 and Mintel 2003 for an overview), understanding of tourist experiences and perceptions of visiting places associated with film and television (TV) remains relatively undeveloped. The incidence of screen tourism has been recognised for some time, but direct measurement of its impact has proved difficult (Busby and Klug 2001), particularly in terms of capturing the screen tourist in field studies. Consequently, meaningful insights into the consumer experience are limited, restricting both the advancement of screen tourism research and the development of principles to harness, manage and benefit from associated tourism activity in destinations. Indeed, for destination managers, identifying the extent to which visits are induced by film and TV viewing is imperative if the benefits of such visits are to be achieved and central to this is gaining an understanding of visit experiences with a view to managing and marketing destinations in an appropriate manner. In particular, a pertinent issue for tourism marketers is tapping the interest created by film to stimulate return visits in the longer-term, thereby generating potential for sustained place interest, association and activity in destinations.

The generic term screen tourism is adopted in this paper to describe tourism that is generated by TV programmes, video, DVD as well as film, that is, small and big screen productions (but not TV programmes designed primarily to promote tourist destinations, such as holiday shows). The author considers the widespread use of the term film tourism (see Evans 1997) to somewhat downplay the importance of TV programmes in stimulating tourism and thus screen tourism is a neater way to define the phenomenon (see also Olsberg|SPI 2007). This paper contributes to the 
understanding of the subject by using a structural equation modelling approach to explore some of the issues induced by an evaluation of visit experiences and the perceived likelihood of repeat visits, generating a range of widely applicable implications for screen tourism destination management and development. Specifically, the paper utilises the findings of empirical research at a micro-level on screen tourists to explore three areas of enquiry. First, the degree to which people are attracted to a location through film connections and the type of visits that emerge from investigative study are explored. Second, the nature of visit experiences is analysed, allowing some consideration of emerging issues for both visitors and the destination. Third, the visitor propensity to return on a future visit is examined. The geographic focus of the research is the Isle of Mull, Scotland, the filming location for the children's TV show Balamory. The paper provides an update to an earlier paper published in Tourism Management (Connell 2005a), which discussed the perception of impacts by the tourism business community on the Island, indicating that the study of visitor perceptions would form a useful future area of inquiry in order to more fully understand the screen tourism phenomenon. Balamory, while a children's show, is a key production to study due to the unprecedented increase in visitor numbers that it created, which has now been acknowledged nationally in UK Film Council sponsored research (SPI|Olsberg 2007).

\section{A DEVELOPING RESEARCH AGENDA}

By means of a brief introduction to the research context of screen tourism, it is apposite to highlight the major themes within the tourism research literature, which demonstrate the significance of screen tourism and the need to recognise the implications of associated activities. Studies of the relationships between film, TV and tourism are relatively new, and in development mainly since the early 1990s given the growing recognition of screen tourism as an identifiable phenomenon. The major themes include:

1. Identification of screen tourism activity. The earliest screen tourism studies (see Butts 1992; Riley and van Doren 1992; Riley, Baker and van Doren 1998) established the existence of this form of tourism, highlighted relevant issues and initiated further research. More recent research highlights the occurrence of screen tourism through case examples throughout the world (Beeton 2005; Mintel 2003). Initially, most screen tourism research focused on activity in USA, UK, New Zealand and Australia, 
although research activity has widened to mainland Europe and Asia, reflecting the spread of the phenomenon.

2. Impacts of screen tourism on host destinations. The emphasis of a great deal of screen tourism research to date lies within the cluster of research focusing on destination impacts. Central to this strand is the principle of managing destination impacts to gain maximum economic benefit while minimising cultural and environmental damage, community disturbance, disruption of longer-term tourism products and markets, and resident well-being (see Beeton 2005, 2004, 2001; Connell 2005a, 2005b; Croy and Walker 2003; Hudson and Ritchie 2006a; Mordue 2001, 1999; O’Neill, Butts and Busby 2005; Riley, Baker and Van Doren 1998; Tooke and Baker 1996). Much of this work relates to specific case studies.

3. Screen tourism, marketing and destination image formation. A number of studies highlight applied approaches to destination marketing to induce economic benefits through film and TV exposure (Hudson and Ritchie 2006a, 2006b), revealed particularly in the example of the New Zealand Government's vigorous promotion and development of Lord of the Rings themes and activities (Carl, Kindon and Smith 2007; Tzanelli 2004; Jones and Smith 2005). Related to this strand is the idea of image formation and propensity to visit through viewing places on-screen (Kim and Richardson 2003; Warwick, Bojanic and Siriangkul 2004).

4. The characteristics and motivations of screen tourists. While a few studies focus on screen tourists, the area remains substantially unexplored in the academic literature compared with destination impact studies. Busby and Klug's (2001) and Beeton's (2001) surveys derive the characteristics of screen tourists in two screen destinations, while Macionis (2004), Singh and Best (2004) and Chan (2007) develop the field by examining motivations.

5. The experiences of screen tourists. More recent studies by Kim, Agrusa, Lee and Chon (2007) and Carl, Kindon and Smith (2007) have examined tourist experiences, but this remains an emerging area of work that would benefit from further empirical studies that delineate, illustrate and evaluate the nature of screen tourism and the implications for destinations. It is to this relatively uncharted area that this paper is directed. It aims to progress understanding of the appeal of screen tourism destinations, the experience of visiting, the likelihood of return visits and the implications for tourism destination marketing and management. Prior to discussion 
of empirical work, a review of literature and applied research relating to these subjects of enquiry is presented.

\section{The tourism appeal of screen destinations}

As much of the literature recognises, capitalising on the positive impacts of screen tourism can assist in the strategic development of tourism activity in destinations by supplementing the product portfolio, increasing tourist awareness and appeal of the destination, and in turn contributing to the viability of tourism, a concept that has been recognised for some time (see Butler 1990; Riley and van Doren 1992; Croy and Walker 2003) and well-established in research literature (see e.g. Riley, Baker and van Doren 1998; Mintel 2003; Beeton 2005; Olsberg|SPI 2007). Film and TV scenes and images have the potential to endure for many years, creating a powerful and alluring destination product or experience (Morgan and Pritchard 1998), although it is the interplay of landscape qualities and icons, storylines and characters, and the extent to which locations act as a significant feature in filming that is likely to induce visits (Riley and van Doren 1992; Riley, Baker and van Doren 1998). In this respect, screen-induced tourism is only likely to follow where locations are effectively transcribed from film to reality and where landscape, place and emotional associations are strong (Escher and Zimmerman 2001; Olsberg|SPI 2007). There are many examples where filming took place in substitute locations but still stimulated tourism in the places that were intended to be portrayed (e.g. Braveheart (1995) caused a tourism boom in Scotland due to its depiction of William Wallace and the fight for Scottish independence, but was filmed mostly in Ireland). This suggests that real place settings can be confused with - and even less important to tourists than - imagined ones, the central tenet of Eco's (1986) hyperreality concept as applied to screen tourism. Conversely, fans of cult film and TV tend to undertake inordinate amounts of research to seek out film locations, some of which may be 'underground', i.e. not promoted or commercialised (Hills 2002).

Yet, as Doyle (2003) comments, screen tourism is generally not on the agenda when programmes are made, and essentially an incidental form of tourism (or accidental as Beeton (2004) describes). However, to capitalise on screen links, destination marketing organisations occasionally plan and execute direct campaigns to promote movie locations and themes with a view to stimulating visits (e.g. VisitScotland's 
$£ 1.3 \mathrm{~m}$ European campaign in collaboration with Sony Pictures to promote Da Vinci Code locations, and the notable international marketing campaign to stimulate visits to the USA in 2004 devised by the Visit America Alliance using movie locations with the catchline 'you've seen the movies, now visit the set'). The existence of dedicated units in national tourism organisations, local authorities and local tourism agencies to facilitate both filming and screen tourism is testament to the importance placed on the power of film and TV in generating visits to locations.

\section{The experiences of screen tourists}

There is a gap in the research literature with regard to the on-site experiences of screen tourists and consequently there is little understanding of how screen tourists perceive, interact and relate to the destination. Through Macionis (2004) and Singh and Best, some breakthroughs have been made in terms of understanding motivation, but further research is needed to understand screen tourism experiences in destinations. A recent research study focusing on participants on Lord of the Rings tours in New Zealand identified that hyper-reality played an important role in screen tourist satisfaction, and that the higher the degree of involvement and consumption, the more enhanced the tourist experience (Carl, Kindon and Smith 2007). The findings of this LOTR study provide a useful basis on which to test this idea in other contexts, particular where no direct screen products or services have been developed to capitalise on screen tourism. Similarly, Couldry's work on Coronation Street (1998, 2005) provides useful insights but focuses on visits to a simulated film set. What the research in this paper is concerned with is the experiences of visitors to a real place that was used as the backdrop to a TV programme, where there are no commercial tours or screen-related services on offer.

A further issue is probing the extent to which screen tourists are drawn to a place just to see a filming location. Macionis and Sparks (2006) state that most screen tourists are incidental (i.e. just happen to be at the destination) but increasing evidence, especially from UK research (see Olsberg|SPI 2007), implies that huge increases in visitors correspond with film and TV showcasing, indicating that the importance of screen tourism as a drawcard should not be underestimated. 
Screen tourism and the longer-term: generating repeat visits

Critics of screen tourism, as a means of sustaining tourism in destinations, point to the limited duration of interest in film, TV and related sites as a disadvantage in strategic planning. Indeed, Riley and van Doren (1992), using Ritchie's definition of a hallmark event, claim destination-based screen tourism to be of limited duration, rather like the tourism attraction life-cycle (see Lennon 2001). Yet, as Beeton (2005) highlights, screen tourism is more appropriately defined as a pilgrimage that displays an element of longevity, particularly in the case of televised drama. Indeed, while film (specifically film rather than TV) tourism activity tends to reach peak interest following the launch of a film, the enduring qualities of some film and TV outputs often draw visitors for many years post-launch (Riley, Baker and van Doren 1998) or termination of TV series. A number of examples demonstrate the longevity of screeninduced tourism, although much evidence remains anecdotal. However, some corroborating data does exist, which illustrates current activities associated with UK film and TV that in some cases is inspired by productions first screened more than 40 years ago (see Table 1).

\section{TABLE 1}

Interestingly, many of these appear to be 'cult' offerings (i.e. popular within a selfidentified grouping of dedicated fans to whom a particular theme appeals), where the initial fan base has been supplemented by new viewers through TV repeats and release of pre-recorded video and DVD products. Arguably, a long-running TV series is more likely to sustain interest, given the likelihood of viewer interest in place, stories and characters and the opportunities afforded by long-term association for destination marketers in product placement or for studio tours (see e.g. Couldry's (1998) analysis of the British continuing drama Coronation Street). For destinations, harnessing long-term associations through attention to the visit experience, visitor satisfaction and creating sustained appeal, thereby generating repeat visits from an initially film-induced visit, presents opportunities and challenges, as indicated in the literature on screen tourism destination impacts. This is particularly the case given that like literary-induced tourists, to whom screen tourists have been likened (Beeton 2005), visitors tend to be visiting the location for the first time and usually mirror the reader profile (Pocock 1992) or, in the case of screen tourism, 'viewer' profile. 
Accordingly, grasping first-time visits and transforming these into repeat visits will create a legacy of screen tourism.

The literature on repeat visiting is even less well-developed than that of screen tourism, although within the field of Marketing it is well-established that maintaining a long-term relationship with customers achieves competitive advantage and reduces the cost of attracting new custom (Kotler and Armstrong 2007; Jobber 2006). According to this approach, the intention and willingness of customers to repeat purchase depends upon the level of their satisfaction with the product or service, where if they are satisfied they will be more likely to purchase again. In a tourism context, long-range planning and generating customer satisfaction should be the two major objectives of tourism businesses and destinations in maintaining competitive advantage, the key element of destination management and marketing strategy (Ritchie and Crouch 2003). While visitor satisfaction is a highly complex subject (Ryan 2002) that can be affected by the interplay of internal and external factors, Kozak (2001) suggests that the overall level of visitor satisfaction has the greatest impact on the intention to revisit the same destination, indicating that experience with a particular destination could stimulate future behaviour and repeat visits. Gitelson and Crompton (1984) identified five factors that influenced repeat visitation, including: reduced risk of an unsatisfactory experience; likelihood of mixing with "their kind of people"; re-experiencing an emotional childhood attachment to a location; engaging in aspects of the destination which had been omitted on a previous visit; and to introduce others to a location previously enjoyed. These factors should be considered in addition to the tourist simply wishing to re-experience an enjoyable location or memory. However, Tak-Kee and Wan (2006) argue that tourists' overall satisfaction level is an insignificant predictor of repeat visiting, with variables such as climate, attractions, and facilities of greater significance. Nevertheless, more empirical knowledge of the determinants of repeat visiting is likely to be useful to policymakers attempting to develop, improve and secure the economic benefits of repeat visiting (Darnell and Johnson 2001) to screen destinations.

The legacy of screen tourism (see Beeton 2004), as a product that can clearly stimulate visitor activity in the short-term, could be to sustain tourism in the long-term Rather than being reliant on new tourists, capturing the imagination and loyalty of 
first-time screen visitors to a region and stimulating repeat visits, perhaps to discover more about a destination other than its screen connections, can assist in the strategic tourism development process, if carefully managed in suitable destinations. This aspect now forms part of an analysis of screen tourist perspectives in a Scottish case study.

\section{A SCREEN TOURISM DESTINATION: SCOTLAND, THE ISLE OF MULL AND}

\section{BALAMORY}

Scotland is well-established as a screen tourism destination and the national tourism organisation, VisitScotland, has long acknowledged its importance (see Hydra Associates 1997). Scotland provides a diverse range of locations that form a backdrop to small and big screen productions (Scottish Screen 2007a) and on average, twelve large scale films and eight TV dramas are filmed each year in the country (Scottish Screen 2007b). Scottish locations are famously portrayed in a range of films, from the stunning sands of St. Andrews Chariots of Fire (1981), to the Highland landscapes of The Water Horse (2007) and the mean streets of pre-regenerated Leith in Trainspotting (1996). Indeed, Local Hero (1983) filmed in Pennan (Aberdeenshire) and Morar (West Highlands) was voted by film critics and writers in 2005 as creating the strongest sense of place and the most atmospheric use of a British location (Film Distributor's Association 2005). Principally, international screen tourist interest in Scotland was created in the 1990s by a cluster of films and TV series related to Scotland, including two blockbuster movies Braveheart (1995)(see Edensor 2005) and Rob Roy (1995), and two TV series Hamish Macbeth (1995-7) and Monarch of the Glen (2000-5), all of which utilise Scottish tradition, mythology and landscape to varying degrees. Filming of major scenes in, for example, Four Weddings and a Funeral (1994), Mrs Brown (1997), The Queen (2006), The Da Vinci Code (2006), Harry Potter and the Order of the Phoenix (2007) and Doomsday (2008) have further validated Scotland as an international screen location. One of the most visited screen destinations in recent years has been the Isle of Mull, with the huge popularity of the pre-school children's TV programme Balamory (BBC Scotland 2002-5).

The Isle of Mull (pop. approx. 3,000) is situated on the west coast of Scotland (see Figure 1) and renowned for its natural beauty, wildlife, dramatic landscapes, unspoilt coastlines and castles. 


\section{FIGURE 1}

The Island, which is only accessible by ferry, accommodates around 400,000 visits per year. It has played host to the filming of several movies (or movie scenes) including Entrapment (1999), I Know Where I Am Going (1945) and When Eight Bells Toll (1971) (Bruce 1996; Pendreigh 2002), although was not a major screen destination until 2003. Since then, the tiny capital town Tobermory, famed for its iconic painted harbourside houses often depicted in Scottish tourism promotional imagery, has become a screen tourism highlight for those seeking the real Balamory. The programme is filmed in the town using the exteriors of several painted houses which appear throughout the show, and in the opening and closing graphics. The houses are a prominent feature in each programme, immortalised in the theme song that includes the refrain "which coloured house are we going to...?" Balamory is unique in several ways for Mull, for it is the only TV series filmed on the Island and the only production to create a mass tourist influx there. Viewing figures in the UK were estimated at 750,000 per episode in 2004 (BBC Worldwide 2004) and many episodes are available on video and DVD as well as the BBC digital channel Cbeebies, extending and prolonging Tobermory's exposure to the audience well into the future. More recently, Balamory has been transmitted to a worldwide audience through BBC Prime.

A curiosity to see the coloured houses and the filming location for the show quickly transformed Tobermory into a 'must-visit' destination for families with young children. The number of additional tourists to the island has risen by about 150,000 per year, and these extra visitors are predominantly families (Argyll, the Isles, Loch Lomond, Stirling and the Trossachs (AILLST) Tourist Board 2003). The 'Balamory effect' was greeted with both a positive and negative reception in the local community. Connell (2005a) reported that about $50 \%$ of business across the Island, and $75 \%$ in Tobermory, saw a rise in the number of tourists due to the desire to 'see Balamory'. However, accommodation and transport providers experienced capacity related problems, and some tourism business operators expressed a number of concerns (Crilly 2004; Ross 2004). Anecdotal evidence claimed that tourist expectations were not always met, with no Balamory-based features or attractions 
apart from the exteriors of the coloured houses used in filming (which are private residences), and few child-oriented services (Kelbie 2005; Reid 2004; Seenan 2004). No consultation with stakeholders occurred prior to selecting the filming location, primarily because there was no prediction of the boost in visitor numbers. Consequently, the show's producers, along with the local community and tourism organisations, were taken by surprise at the show's success and the subsequent allure of Tobermory. The flood of visitors was even more astonishing given the initial absence of place promotion of the town as Balamory (Connell 2005b), and its relative remoteness. These issues are discussed in-depth by Connell (2005a, 2005b) but one of the problems is that there is no understanding (based on empirical data) of who visitors are and what experiences they have, thus the implications for planning and management of tourism for the benefit of host and guest are only partially explored in this case. An appreciation of visit characteristics and experiences is required to determine current issues and those relating to the longer term development of screen tourism, given that the legacy of Balamory is likely to be the existence of a new generation of tourists brought up watching the show.

Accordingly, the justification of an investigation to identify and evaluate visits to see the setting of the show is clear: to gain insights into visitor activity, perceptions and experiences which can assist in deriving indicators and actions for tourism management, marketing and development at the local level, while yielding more widely applicable principles. The paper now turns to the findings of an empirical study of visitors to Balamory.

\section{Research Methods}

The primary aim of the research was to explore the responses of family groups, whose visit to the Isle of Mull incorporated a trip to see the real-life film location of Balamory, in relation to their visit experiences. The objectives of the research sought to identify the degree of influence of Balamory on a visit to the Isle of Mull, visit characteristics, visit experiences and the likelihood of a return visit being made. Central to this process was the identification and evaluation of the audience, thus a suitable research method was required. 
The main research tool was a three-page questionnaire administered to tourists on afternoon ferry crossings, to target those returning from a visit to the Island (i.e. Craignure-Oban as in Figure 1: a 45-minute journey). On embarkation, and when possible, in the embarkation queue, adults with young children (notionally 6 years old and under) were systematically approached to ascertain if a visit to 'Balamory' had formed part of the family visit to the Island. If so, one adult from each family group was asked to complete a questionnaire, a commonly used method in family-oriented research (Nickerson and Jurowski 2001), while three questions were directed at the respondent's child/children with permission (and where appropriate given age-related constraints on answering).

The data collection period was set over six weeks in the summer peak season. Some 195 usable questionnaires were generated for analysis. The non-response rate was about $30 \%$, subject to changes in climate, with higher numbers of refusals on extremely hot or wet days when children required more attention (i.e. higher levels of antagonism) and better rates when the weather was more equable. No other patterns of non-response were noticeable, except that the small number of overseas families approached did not feel able to answer the survey. As a result, the survey was confined to domestic tourists, which is not viewed as a constraint as the televisation of Balamory overseas was limited at the time, and also reflects the visitor profile to Mull. The sample size is the same sample size as that achieved in the Mull Visitor Survey (Argyll and the Isles Enterprise, Argyll, the Isles, Loch Lomond, Stirling and the Trossachs Tourist Board, Argyll and Bute Council, Scottish Tourist Board and Highlands and Islands Enterprise 2000), and therefore judged as a suitable representation.

The decision to undertake the survey on the ferry rather than in Tobermory was dominated by several factors, but mainly because capturing responses in the town would have been inefficient. The spatial configuration of the town meant that tourists were dispersed and there were no effective survey points at which to capture respondents. Second, it would have been irresponsible to ask for survey information from a carer with responsibility for children, given that there were few safe places to stop in Tobermory (recognising the dangers of combining excited children, narrow pavements, traffic and the harbourside). Third, when approaching tourists it might not 
be clear whether they have spent enough time in Tobermory to be able to answer the questions. Last, it would have been unfair to target tourists leaving Tobermory, who were often concerned about leaving on time to get a seat on a bus and to catch the ferry home. Undertaking the survey on-board the ferry offered solutions to these difficulties.

Four key elements formed the structure of the questionnaire: first, gaining information on the tourist and the visit, including the degree to which Balamory was the main driver of the visit; second, an assessment of tourist behaviour and on-site activity; third, gauging the degree of satisfaction with the visit, exploring those aspects of the visit most liked and most disliked from the perspective of both the carer and the child. A final element focused on whether a return visit might be likely in the future based on this visit. A five-point Likert scale was employed to assess expectations prior to the visit, in conjunction with experiences gained on the trip, while likes and dislikes were gained through open questioning. The use of an open style question to gauge experiences dispensed with concern over potential researcher bias in deriving closed categories.

A limitation of the survey is that it was mainly, although not exclusively, captured foot passengers, due to embarkation and disembarkation logistics. However, this was not seen as an undue constraint, as observations and advice from the ferry operators revealed that most Balamory visitors were day visitors on foot rather than those using the car or coach. The research process did not allow for in-depth interactions with respondents given the limited amount of time available to interview passengers on the ferry.

\section{DISCUSSION OF FINDINGS}

Acknowledging the above limitations, findings are now explored, in two dimensions. First, a descriptive analysis, using basic frequencies, cross-tabulations and chi-squared analysis where appropriate, reports on visit characteristics, the degree of importance of Balamory in stimulating the visit, visit experiences and degree of satisfaction/dissatisfaction associated with the visit. Following this, a structural equation model approach is developed and presented to explore relationships and 
meanings through multiple dimensions of visit characteristics, experiences and propensity to make a return visit.

\section{Types of Visits to Balamory}

Analysis of the data indicates that $96 \%$ of respondents were visiting Mull for the day, while $81 \%$ of the sample was on holiday. Most day visitors had started their journey from within the Argyll and Bute area, with the greatest proportion (40\%) from Oban, although $16 \%$ had travelled some distance (80-120 miles). Most of those travelling longer distances were on day trips from home, indicating a significant destination draw when one combines a car journey on the remote and twisting singlecarriageways of the region with the demands of a young family. Further, those on a day trip from home were more likely to be visiting just to see the film location than those visiting from a holiday base other than Mull (46.4\% compared with 32.9\% of visitors). Postal code analysis revealed that some $34 \%$ of the sample lived in Scotland, with a concentration in the Glasgow area, the nearest large urban centre.

In line with Pocock (1992), 70\% of visitors were first-time visitors to Mull. The dominant form of group composition was parents with children $(67 \%$ of all respondents, with $53 \%$ composed of two parents and children). Some $91 \%$ of the sample was composed of groups with one to three children. The age profile of children in the Balamory survey clearly corresponded with the pre-school focus of 'Balamory', with $41 \%$ of children aged three to five years, and $67 \%$ aged two to six years. These findings provide evidence of the significant number of young and very young children travelling with their families to Mull to 'see Balamory' as reported by the Tourist Board (Dehany 2003 personal communication).

\section{Establishing the Degree of Importance of Balamory in Stimulating the Visit}

Clearly portrayed by the survey findings was the desire to visit Tobermory for its role as Balamory, with some $69 \%$ of the respondents stating that they would not have made their visit to Mull otherwise. Using Macionis's (2004) categorisation that identifies specific, general and serendipitous film tourists, the results indicate that Balamory attracts a large proportion of specific screen tourists, who actively seek out places portrayed on TV. This finding is quite startling given that there was little active promotion of Balamory at this time, but highlights the strong appeal of the images 
viewed on TV. An examination of the data relating to the extent to which Balamory was an attractor for the visit that day, 'seeing Balamory' (i.e. the film location, primarily the coloured houses) was the single most significant motive for visits, with $34 \%$ of respondents visiting simply to 'see Balamory'. A further $36 \%$ of respondents visited to 'see Balamory and to explore Tobermory'. Much fewer visits were 'general' (14.5\%), made to 'see Balamory and other places on Mull', and 'serendipitous', where visitors went to Tobermory as part of a visit to see the island (14\%). The data suggests the emergence of an additional category of visitor that supplements Macionis's (2004) spectrum, the 'elite' visitor, who is visiting purely to view the filming location with no other motive, while 'specific' visitors specifically travel to see the film location and explore the immediate vicinity while there.

An evaluation of the data reveals several distinctive differences between 'elite' visits made 'just to see Balamory' and other types of visit, hinting at the existence of a typical Balamory-induced visitor/visit. While Table 2 outlines some of the main characteristics of tourists, other differences between visits that were made 'just to see Balamory' compared with other types of visits that are noteworthy include the composition of groups and the perception of the visit. More visitors in this category were grandparents with children (15.3\%), compared with $7.4 \%$ when the visit to Balamory was more incidental. Elite tourist visits were more likely to be prompted by children rather than carer/parent. Due to the focus of the visit, these respondents were more likely than others to visit all the coloured houses (84.6\% compared with $61.5 \%$ of those who were visiting Balamory as part of a trip to see the Isle of Mull) and buy souvenirs (84.6\% compared with 50\%), significant at the $99 \%$ confidence level. Of all those concerned about the safety of children in the destination, by far the greatest level of concern was expressed by those visiting just to see Balamory. Similarly, of all those visitors disappointed with their visit, more than half were elite screen tourists.

\section{TABLE 2}

Pre-visit Information Search 
One of the problems of Balamory-related tourism as perceived by businesses on the island is that most of these tourists have little knowledge or idea about the geography of Mull and its limited infrastructure in terms of roads, accommodation and facilities (Connell 2005b). The survey indicated that a significant number of people had gained some information prior to visiting, but $31 \%$ did not know much, while $4 \%$ admitted to knowing nothing at all about the island. This data suggests that about one-third of film-induced tourists do not know what to expect from their visit to the island. In addition, a negative correlation was found between research prior to the visit and time expected to spend on visit (chi-squared $\mathrm{p}=0.001$ ) and lots to do for children in Tobermory (chi-squared $\mathrm{p}=0.003$ ), and both factors related to visit disappointment. Such a finding would seem to contradict Hill's (2002) analysis that fans research film locations thoroughly. Such findings raise implications for the marketing of the destination where essential information to potential tourists (such as awareness of limited public transport, length of journey and facilities on offer) is not transmitted prior to travel. Despite the best efforts of marketing bodies on the Island, if tourists fail to gain information before travel, through a tunnel vision approach to "we must see Balamory", then expectations may not match actual experience and subsequent levels of satisfaction. The findings indicated that Tourist Information Centres and websites were the most used sources of visit information, suggesting that a stronger message about the realities of the Island should be portrayed in these sources.

Information provision is important because knowing the amount of time available to spend on the Island can be a major dictate of activity choices, and subsequent visit experiences. For foot passenger day trips, time in Tobermory is restricted according to the limited bus and ferry timetables. Accordingly, $43 \%$ of respondents spent a morning or an afternoon in Tobermory, while 35\% spent between one and two hours. Some $19 \%$ spent a whole day, although these respondents were more likely to be staying overnight rather than day-trippers. For nearly three-quarters of respondents, this was about the amount of time expected to spend. However, 22\% stated that they had spent less time than expected, which suggests that tourists may have higher expectations of what Tobermory has to offer than in reality. In addition, one-quarter of respondents thought that the journey from the ferry port to Tobermory was longer than they had anticipated. These findings raise serious issues for the local tourism industry on Mull, and those engaged more widely in screen tourism destination 
management in terms of meeting expectations through pragmatic marketing approaches.

\section{Evaluating the Experiences of Screen-Induced Tourists}

Responses to attitude statements are summarised in Table 3. While the majority of respondents were satisfied with their visit, not all experiences were positive. A responsive tourism industry needs to be aware of what causes dissatisfaction and thus it is important to explore these factors. Some $28.7 \%$ of adult respondents were disappointed with their trip (although only $16.3 \%$ of children were very disappointed). Visit disappointment appears to be relatively low for children, but somewhat higher for adult respondents, indicating that parents/carers have a more finely tuned notion of the leisure experience they want their children to have, which may exceed the actual satisfaction level of children themselves. An overriding theme derived from the results was that respondents expected more Balamory-related activities, as well as more for children to do. A mere $14.7 \%$ thought that there were lots of things for children to do in Tobermory.

\section{TABLE 3}

Further probing of those respondents who were disappointed by their visit reveals some interesting patterns. First, there was a slightly higher level of disappointment from children who would not have visited otherwise. Second, those who had visited just to see Balamory were more likely to be disappointed by their visit (34.9\%) compared with all other groups. Third, of the respondents stating that they or their children were disappointed by the trip, most had not undertaken much research about the destination before the trip and spent less time than they had expected at the destination. These respondents had not visited other attractions on the Island. A significant number of disappointed visitors were on day visits from home (chi-squared $\mathrm{p}<0.000$ ), who had in some cases travelled some distance. Finally, the data indicates that there may be some relationship between age of children and disappointment with visit, where those with older children more likely to be disappointed than those with younger children. 
Features of the trip that were liked and disliked were ascertained through open questions, directed at the respondent and the children in the group and yielding a diverse range of responses, illustrated in Figures 2, 3, 4 and 5. For ease of coding and manipulation, open answers were categorised to form a smaller number of responses. Ultimately, open questioning provides a useful approach as the respondent's views are expressed, revealing both the most positive and problematic areas of screen tourism as perceived by the respondent. Feedback of this nature can help to inform tourism policy and provision, where appropriate, given planning and budgetary constraints and acknowledging that screen tourism may not be an economically sustainable option in the long-term (Riley, Baker and Van Doren 1998). Figure 2 highlights the importance of scenery and place components, although the pleasure induced by seeing children's enjoyment at visiting Balamory is clear. For children, seeing the show's icon, the coloured houses, was the highlight of the trip, along with other coloured house-related activities (such as finding the houses or visiting a particular house) (Figure 3), reinforcing the idea of seeking iconic features in screen tourism.

\section{FIGURES $2 \& 3$}

In relation to aspects of the visit that were liked less, there were many similarities between carers and children's viewpoints (see Figures 4 and 5). As in most visitor surveys, the least liked feature of the visit was bad weather for both groups. For carers, by far the most significant area of concern was over transport difficulties (length of bus journey, cost of ferry, and rush for buses). In peak season at peak times, lack of capacity was a major problem for local transport providers on Mull, with the increased level of demand that could not be easily accommodated on scheduled services and with a limited fleet. For children, not meeting Balamory characters, not being able to go into the coloured houses and not much provided that was to do with Balamory were the main areas of complaint.

\section{FIGURES 4 \& 5}

These findings indicate a need for flexible, innovative and short-term solutions within the destination for screen tourists, but as Connell (2005b) points out, most operators are not prepared to make investments given perceived investment costs and the 
perceived limited longevity of the product. Indeed, visitor dislikes shared much in common with the concerns of businesses and local residents, many of whom considered some of the existing public sector infrastructure used both by tourists and residents alike to be in need of improvement (e.g. transport services and local facilities such as toilets and play parks) as reported by Connell (2005b). Interestingly, this points to a need for communication between tourists, agencies and the local business sector, as the perceptions of businesses did not necessarily match the views of tourists. Only $17.2 \%$ of respondents who suggested screen-related improvements to the destination wanted to see a visitor centre, with the majority desiring to see shortterm and relatively simple innovations, such as cardboard cut-outs of characters, characters dressed up, leaflets, quizzes, maps, tours and plaques on the coloured houses. Of the whole sample, $32.3 \%$ suggested that improvements to the general infrastructure of the destination were needed such as easier transport and play areas for children.

In making sense of the various features of visits that were liked and disliked by adults and children, a basic frequency analysis of the major aspects (for pragmatism, taken as all responses achieving more than 5\%) revealed a useful distinction between destination-related and screen-related components. Table 4 shows that a much higher proportion of aspects liked and disliked by adults were destination-related (e.g. scenery, beach, costs, transport) than screen-related. Conversely, for children a higher proportion of features liked were screen-related. However, dislikes were more likely to be destination-related. While this is a relatively crude measure, it does give an indication of the importance of screen-related elements opposed to destination elements and suggests that an attractive destination with good facilities could hypothetically underpin the success of a screen-induced tourism destination.

\section{TABLE 4}

\section{Propensity to Return}

For the tourism industry, gaining loyal custom is an efficient and attractive means of doing business, but a major concern with screen tourism is that it only creates shortterm interest. The findings in this study indicate a large proportion of respondents intend to return for another trip $(66.5 \%$ in total, with $32 \%$ stating that they would 
definitely return). Most encouraging for the tourism sector in this destination, keen to stimulate more overnight stays rather than day trips, is the $15 \%$ of respondents stating that they would return for a long holiday (4+ nights), and a further $47 \%$ who said they were more likely to return for a short break (1-3 nights). Of those that expressed that they would definitely return, a larger proportion were first-time visitors $(\mathrm{p}=0.05)$, and $77.8 \%$ of respondents that had arrived specifically to see Balamory said that a return visit was likely. A significant relationship was found between those who visited other attractions and the likelihood of a return visit (chi-squared 9.409, df.4, $\mathrm{p}=0.052$ ).

Some $27.9 \%$ of those who said that they were disappointed with their visit stated that they would definitely not return for another visit and a significant relationship between 'disappointed with visit' and 'return visit likely' was identified (chi-squared 50.617 , df.16, $\mathrm{p}<0.000$ ). These issues are now further explored through structural equation modelling.

\section{UNDERSTANDING VISIT EXPERIENCES, CHARACTERISTICS AND PROPENSITY TO RETURN THROUGH STRUCTURAL EQUATION MODELLING}

A structural equation model has been developed using AMOS version 5 to further explore the relationships between visit characteristics, child and adult visit experiences and likelihood of making a return visit to the Island. The underlying constructs were designed in accordance with these research areas with some assistance from exploratory factor analysis. There are numerous goodness of fit statistics for these models, but according to Byrne (2001) the root mean square of approximation (RMSEA) suggested by Browne and Cudeck (1993), the normed chisquare (CMIN/DF) first suggested by Wheaton, Muthen, Alwin and Summers (1977), and the comparative fit index (CFI) suggested by Bentler (1990) are three of the most reliable measures. Byrne suggests that models with a CMIN/DF ratio of between one and two may be considered adequate, provided that fit indices such as the CFI are reasonably close to one, preferably above 0.90 . RMSEA values below 0.05 indicate an excellent fit while models with RMSEA values above 0.10 indicate an inappropriate model. 
With sample sizes of less than 200, a maximum likelihood analysis must be performed, assuming that the variables all have a normal distribution. However, in this case, most of the variables are measured on an ordinal scale. Correlations are under-estimated in this situation so the standardised coefficients (beta weights) displayed in our models are probably under-estimated. In the path diagrams of the models straight lines suggest causal links and for the sake of visual simplicity error terms have been omitted from the path diagrams.

To briefly recap, some $34 \%$ of respondents said that a repeat visit was probable while $32 \%$ of respondents said that it was definite. This left $34 \%$ of respondents who were not sure or unlikely to return. Fifty-nine percent of respondents said that they were not disappointed with their trip to Balamory leaving 10\% who were very disappointed with their trip, $17 \%$ who were disappointed to some extent and $10 \%$ who were unsure regarding their level of disappointment. However, it seems that the children were more appreciative of the trip with $68 \%$ of respondents claiming that the children were not disappointed with only $6 \%$ of children being very disappointed, $10 \%$ being disappointed to some extent and 13\% unsure. A Wilcoxon Signed Rank test indicated a significant different difference between the views of parent/carers and the views of the children as reported by the parent/carers $(\mathrm{z}=3.972, \mathrm{p}<0.001)$.

As expected there was a significant relationship between the attitudes of parent/carers and the attitudes of the children (Kendall's tau_b $=0.610, p<0.001$ ). However, there was a stronger correlation with the likelihood of a return visit in the case of the parent/carer's view (Kendall's tau_b $=0.297, \mathrm{p}<0.001$ ) than in the case of the reported children's view (Kendall's tau_b $=0.253, \mathrm{p}<0.001$ ). This suggested a model in which children's view had an influence on adult's views, but adult views determined whether a return trip would be likely.

Structural equation modelling was used to formulate a model for child and adult disappointment, as well as the decision regarding a return trip. The fit was reasonably good for this model $(\mathrm{CMIN} / \mathrm{DF}=1.649$, RMSEA $=0.058, \mathrm{CFI}=0.90)$. In this model, shown in Figure 6, there is an indirect link between children's level of disappointment and the likelihood of a return visit, with mediation by the adult level of disappointment, but there is no direct link between the views of children and the 
likelihood of a return visit, which was found to be insignificant $(\mathrm{CR}=0.85, \mathrm{p}=$ $0.394)$.

\section{FIGURE 6}

Other interesting aspects of the model included the variables that weighted more strongly in the prediction of child disappointment than parent/carer disappointment. Two of the variables, "More Balamory activities expected" $(\beta=0.38)$ and "Coloured houses were the highlight for the kids" $(\beta=0.19)$ can probably be attributed to genuine reactions on the part of the children. Children were more disappointed with their trip if they expected more Balamory activities and more satisfied with their trip if they loved the coloured houses. However, the inclusion of "Balamory promoted too much" and "Good value for money" in the model for children's disappointment seem inappropriate, suggesting that the reported reaction of the children was coloured by the response of parents/carers to these issues. This is confirmed by the direct links between these variables and the likelihood of a return visit. Good value for money certainly increased the likelihood of a return visit $(\beta=0.35)$, in that it was reported to increase child satisfaction $(\beta=0.24)$. However, the over-promotion of Balamory appears to have had a slightly positive impact on the likelihood of a return visit $(\beta=$ $0.10)$, despite some contribution to child disappointment with the trip $(\beta=0.26)$.

Interestingly, disagreement with "Lots for kids to do in Tobermory" was more strongly weighted for adult satisfaction $(\beta=0.23)$ than children's satisfaction $(\beta=$ 0.15 ), and the coloured houses, so importance to the children also added to adult satisfaction slightly $(\beta=0.11)$, confirming that the reaction of the children was important in shaping adult opinions. However, there was evidence of some disappointment for adults in terms of café facilities $(\beta=0.10)$ and the Balamory influence of the visit $(\beta=0.16)$. Overall, it appears that the lower the influence of Balamory for the visit, the higher the level of adult satisfaction. As expected, a return visit was more likely if adult disappointment was lower $(\beta=0.29)$ and if Balamory was not the only reason for the visit $(\beta=0.20)$, especially when there had been previous visits to Mull $(\beta=0.23)$. The age of the first child was negatively correlated with the likelihood of a return visit, suggesting that a return visit was more likely for those families with younger children. 
Overall, the above results suggest that while adult disappointment was strongly related to children's disappointment, it is likely that the adult reaction to prices and Balamory promotion coloured the perception of childhood disappointment. The most important variable for predicting whether there would be a return visit was "good value for money". This sends a clear message to tourism operators targeting families with young children. It seems that parent/carers are happy to indulge the kids provided that the price is not too high. However, it is important that the advertising should not be totally dominated by Balamory, because satisfaction with the visit and the likelihood of a return visit is likely to be higher if Mull's other attractions are also used to promote the destination.

\section{IMPLICATIONS FOR SCREEN TOURISM DESTINATIONS}

While there are a few instances of books, film and TV stimulating childhood interest in place (e.g. the Harry Potter films and A.A. Milne's Winnie-the-Pooh), globally the scale of screen-induced 'toddler tourism' generated by Balamory appears to be, so far, an isolated case but one which illustrates a range of implications for a screen tourism destination, where on-screen portrayal has influenced new visits and created a new market. The findings of this research raise a number of issues relevant to screen tourism development, management and marketing and highlight what can be learned from the example of Balamory.

\section{Conceptual Issues}

While this paper does not aim to develop conceptual issues in depth, some points that emerge from this study that confirm existing ideas are worthy of mention. Primarily, Balamory as a TV programme is place-specific and relies heavily on place imagery. While Balamory as a place is an artificial construction, the screen attributes portrayed, such as the exterior of the coloured houses and the landscape setting, are rooted in reality and available for tourist consumption. As discussed in the previous section, not readily available for consumption are the characters and social setting created by the programme. Tobermory is a real community that bears only a visual resemblance to its screen counterpart. For tourists, the translation of Balamory to reality is essentially the opportunity to look at the coloured houses used in filming, while experiencing the ambience of the real Tobermory. Supporting Eco's (1986) analysis that hyperreality is savoured as an end in itself, conceptions of reality and pretence appear to be mixed 
for Balamory tourists. This is illustrated in a few open answers given by respondents in the survey, when asked about suggested improvements to the destination: "be more like the show", "be more realistic to the programme" and "make it like Disney". Such a finding also confirms the findings of Carl, Kindon and Smith (2007), whose research on Lord of the Rings arrived at similar conclusions. For Balamory visitors, while place setting was a feature liked by respondents, some screen tourists seek hyperreal experiences. In particular, specific tourists, who are just visiting to see the film location, appear to have much greater expectations of the destination than others. These visitors seek out identifiable locations but find that they are forbidden further interaction, i.e. not able to enter houses, see the characters or visit a themed centre. This created disappointment for a small number of children but, interestingly, a larger proportion of adults.

How might this be explained? If tourism is conceptualised through the 'tourist gaze' (Urry 1990), essentially it is a hyperreal experience where, as Eco (1986) argues, there is always 'something to see'. The tourist, and especially the sight-seeing tourist, has become used to experiential-based activities that are produced and packaged, and is well-initiated in the art of passive consumption: indeed, the 'post-tourist' relishes simulated environments for what they are (Feifer 1985). Further, the tourist is drawn to the 'carnivalesque': controlled, safe environments designed for the "de-control of emotions..." (Featherstone 1991: 80). However, the reality is perhaps less intriguing than the imagery, with respondents concerned about issues like value for money, safety, lack of things to do and in particular and a lack of screen-tourism specific facilities to serve their needs. The implications of the blurring of reality and fiction in the case of screen tourism highlight potential management dilemmas for screen tourism destinations, which will now be explored in more detail.

\section{Managing the Screen Tourism Destination}

The results of this research indicate that there are several outcomes concerning the screen tourist destination experience and arising management challenges. The survey findings indicate two broad levels of interest:

1. Acknowledging the toddler tourist as consumer. While this paper is concerned with screen tourist experiences, it is worth briefly noting the existence of the 
child as a consumer of tourism products and experiences in the case of Balamory. In this study, greater satisfaction regarding the visit was expressed by parents/carers where children were satisfied, supporting Thornton, Shaw and Williams' (1997) premise that parents tend to be satisfied when children are happy. Many visits were prompted by a child's wish to see Balamory, while for many parents/carers, the best part of their visit was seeing the look on their child's face when they saw the coloured houses for the first time and seeing their child happy. This finding supports Singh and Best's (2004) research on visitors to the Lord of the Rings movie set, where a major motivation to visit was to satisfy children's interest.

The emergent issue of parent and child perception of experience is an interesting issue for destination managers where, in most cases, children were satisfied with the visual experience of seeing Tobermory's picturesque built environment. Indeed, just going to a real location to see where filming took place is often a highly satisfying experience (Couldry 1998). Conversely, more parents/carers were less satisfied with the visit, expecting more attractions and a greater level of dedicated screen-related activities, along with good tourist services and facilities. James, Jenks and Prout (1998) argue that adults and children can understand and enjoy the same kinds of cultural products, but as Davies (2001) highlights, their product experiences are likely to differ. This appears to be the case in relation to screen tourist experiences of Tobermory, where children show a stronger propensity to be satisfied with their visit than their parents/carers, and emphasise connections with the TV show more strongly in what they liked most and least about the visit. While children are only likely to form a small proportion of screen tourists in the global context, the rise of the child as consumer coupled with increasing participation in cinema attendance by young people (see, for example, Film Council 2007), screen-induced tourism involving children will inevitably occur in other places in much the same way as it has on the Isle of Mull. As an aside, and most interestingly, while other productions since have been predicted to produce a similar screen tourism effect (e.g. Macgregor 2004), this has not happened. Perhaps this outcome is related to the visual identity and strength of a filming location and its appeal to certain target audiences that results in a desire to see 
the location, but research is needed to test this idea by identifying the ingredients of the most powerful screen tourist draw.

2. Recognising types of screen tourists and destination experiences. The research identifies that distinguishing types of screen-induced tourists is important, as the level of expectation and satisfaction can be quite different. This research identifies that the elite screen tourist is more likely to have different perspectives to serendipitous or general screen tourists. Elite screen tourists appear to be more sensitive to the visit environment, seeking out readily consumable products and experiences designed to meet their screen-focused needs. Building on Macionis's (2004) spectrum, this study indicates the existence of an elite category of specific screen tourist, who visits purely to see the film location. In fact, what the data shows is that those respondents who visited just to see the film location were more likely to be dissatisfied than those who were visiting to see other attractions and places on the Island. What is clear from the results of this study is that screen tourists do seek value for money, where such visitors are more likely to buy screen-related merchandise but not at excessive prices. General screen tourists appear to not like too much promotion of screen-related links. Indeed, important for the destination is that the lower the influence of a screen product, the higher the overall satisfaction with the visit, and a return visit is more likely. Striking a balance between visitors' requirements is crucial in this instance, through understanding the existence of types of screen tourists and their subsequent needs. In the instance of Balamory, it was found that the numbers of elite and specific screen tourists was relatively large at $34.7 \%$ and $36 \%$ of the sample respectively, a number likely to be much lower at other film sites, although survey methodologies have yet to be developed to accurately determine relative proportions of types of tourist.

3. The tourist-destination interface. The overall implications of this research study that are more widely applicable to other destinations relate to the quality and suitability of existing tourism infrastructure, the ability of tourism enterprises and operators to manage tourist flows, the availability of good tourist information, the suitability of marketing campaigns, the development 
and delivery of screen-related products and experiences and the legacy of screen tourism in creating repeat visits and long-term interest. In relation to the screen tourist, an interpretation of the factors that appear to generate satisfactory or disappointing visits helps to inform the development of principles for managing screen tourism. While the natural and built landscape and setting of the destination is one of the key factors, other features that remain in the control of tourism enterprises and destination managers include the following points.

- Transfer and accommodation of visitors, transportation, site flows and capabilities affect the physical and perceptual carrying capacities of a destination and affect satisfaction. In the case of Balamory, over-capacity problems on public transport services to and from the destination were a major issue for tourists, which contributed to disappointment with the visit.

- A further significant visit planning issue identified in this study appears to be the availability of pre-visit information about a screen tourism destination. The data showed that greater satisfaction was expressed where some research had taken place prior to the visit, and where the visitor spent more time in the destination and visited other attractions in the destination that were not screen-related. Consequently, a marketing-led approach is required to ensure that tourists are cognisant with the type of environment that they are visiting, and have easy access to carefully targeted information indicating the types of attractions on offer and the amount of time required for a satisfying visit. Instead of building up expectations beyond that which the destination can provide, essential information to visitors should focus on the realistic rather than idealistic. However, marketing and promotion are not always necessary to attract significant numbers to screen sites and the marketing process can be by-passed by avid fans. While some fans care little for organised facilities and commoditization, some market segments do expect some degree of service provision, as shown in the case of Balamory, and it is these visitors who are harder to anticipate and cater for.

- The data suggested that those who were more satisfied with their visits had explored the destination more widely, rather than simply viewing the 
filming location. As such, marketing campaigns designed to add to the experience by encouraging specific screen tourists to take long or short breaks would benefit both the tourist experience and the destination economy, compared with a high intensity of consumptive day visits as in the case of Balamory.

- In this study, respondents proffered an array of suggestions that would have improved their experience, including the creation of Balamoryrelated features and attractions, such as a dedicated visitor centre, character look-alikes in the town, events and tours, more information, more signs and improved mapping of the coloured houses trail, and other themed activities for children. If destination capacities are likely to be exceeded by demand for screen tourism in the long term, a case might be made for timed and managed tours or an off-site film set. However, capital-intensive adaptations to consumer demand pose financial risks, as well as being unpopular with the local community (Riley, Baker and Van Doren 1998; Connell 2005a), as the longevity of place or screen-specific tourism themes cannot be guaranteed through time. Indeed, in the case of Balamory, the BBC announced in 2005 that, after 250 episodes, no more filming would take place (BBC Worldwide 2005), which injected doubt in the mind of the local community about the extent to which the programme would continue as a feature of the Island's tourism product. However, the research shows that the majority of respondents that wanted to see more Balamory themes did not desire a dedicated visitor centre.

- While this research was unable to test actual repeat visits as a result of screen tourism, some indications of the likelihood of a return visit were ascertained. The proportions of potential return visits as the data indicates is quite high and indicates that if a destination visited mainly for screeninduced reasons has wider appeal that has the potential to draw visitors back, then screen tourism has worked as a tool to sustain visitor activity in the longer term, creating a legacy. This is particularly the case for Balamory given that the programme is aimed at children, who once grown up may wish to reawaken pleasant childhood memories with their families by visiting once again, as suggested by Gitelson and Crompton (1984). As 
James et al. (1998), Pretes (1995) and Squire (1994) argue, the power of childhood nostalgia in adults can be strong. While research on adult propensity to re-visit childhood holiday destinations is limited, the legacy of Balamory might be to attract today's 'toddler tourists' back in future years. These issues are worthy of much greater research attention and clearly present future study opportunities in understanding both screen tourism and family tourism. Certainly, longitudinal studies of screen tourism destinations to establish the longevity of film and TV as a visit motivator are required to confirm or dispute these assertions.

\section{FINAL THOUGHTS: SCREEN TOURISM RESEARCH}

It is clear from this study, and previous research, that place-specific film and TV serves as a destination attractor, and that a fascination for visual consumption (see Berger 1972) stimulates and sustains screen tourism as a contemporary tourism phenomenon. To date, much of the work conducted on screen tourism, including this study, takes a case study approach. The consequence of this expanding body of evidence is that the impacts, implications and lessons learned from screen tourism examples are somewhat piecemeal but can be synthesised to form general principles of planning, management and marketing to assist in achieving a balanced and successful destination approach. One of the issues about screen tourism research, particularly in the long term is that gaining accurate data on repeat visits, volume and regularity, while critical in product monitoring and development, is difficult to ascertain. As Oppermann (1998) noted, without this type of information, it is difficult for planners to develop appropriate product offerings and for marketers to package and position the destination to appeal to repeat visitors. While the research presented in this paper goes some way to establishing the experiences of screen tourists and potential for future visits in one destination, further research in time and space is justifiable to confirm, dispute or develop these findings. Results from further research should assist in the development of best practice and policy that destination marketing organisations and host communities can implement if faced with the challenges and opportunities of screen-induced tourism.

However, one of the obstacles to progressing screen tourism research is the major methodological issues in researching the extent to which a screen production 
influences tourism. Consequently, lack of raw data to justify investment and expenditure by local enterprises by public agencies remains a constraint in screen tourism as a tourism and economic strategy worth pursuing. To this end, much more rigorous longitudinal tracking of the impacts of screen tourism using robust methodology developed at regional or even national levels is needed. The need for methodologies to isolate, assess and understand tourism activity and impacts is now at a critical point in pushing forward screen tourism as a significant generator of tourism in local areas. With the ongoing interest in screen tourism across the world, such efforts have never been so timely. 
Table 1 Long-term screen associations and visitor activity in the UK

\begin{tabular}{|c|c|c|c|c|}
\hline Location & Title & Type & $\begin{array}{l}\text { Year } \\
\text { of first } \\
\text { release }\end{array}$ & Current activities \\
\hline $\begin{array}{l}\text { Doune } \\
\text { Castle, } \\
\text { Central } \\
\text { Scotland }\end{array}$ & $\begin{array}{l}\text { Monty } \\
\text { Python and } \\
\text { the Holy } \\
\text { Grail }\end{array}$ & $\begin{array}{l}\text { Film (but } \\
\text { associated } \\
\text { with } \\
\text { comedy TV } \\
\text { series Monty } \\
\text { Python's } \\
\text { Flying } \\
\text { Circus) }\end{array}$ & 1975 & $\begin{array}{l}\text { Film fans from all over the } \\
\text { world contribute about one } \\
\text { third of visitors to Doune } \\
\text { Castle every year ( } 2006 \text { visitor } \\
\text { numbers } 35,401 \text { ). An annual } \\
\text { themed event is held every } \\
\text { September for film fans (since } \\
2004 \text { ). The growth in visitor } \\
\text { numbers to Doune Castle } \\
2005-6 \text { was } 29.2 \% \text {, compared } \\
\text { with } 2.1 \% \text { growth in visits to } \\
\text { all castles in Scotland. }\end{array}$ \\
\hline $\begin{array}{l}\text { Portmeirion, } \\
\text { North Wales }\end{array}$ & $\begin{array}{l}\text { The } \\
\text { Prisoner }\end{array}$ & $\begin{array}{l}\text { Cult TV } \\
\text { Series, } 17 \\
\text { episodes }\end{array}$ & 1967 & $\begin{array}{l}\text { About } 10 \% \text { of annual visitor } \\
\text { numbers }(250,000) \text { are film } \\
\text { fans. Shop in village sells } \\
\text { Prisoner themed gifts. Annual } \\
\text { convention held since } 1978 \text { for } \\
\text { members of the Prisoner } \\
\text { Appreciation Society ( } 1,000 \\
\text { members globally). }\end{array}$ \\
\hline $\begin{array}{l}\text { Thirsk, North } \\
\text { Yorkshire }\end{array}$ & $\begin{array}{l}\text { All } \\
\text { Creatures } \\
\text { Great and } \\
\text { Small }\end{array}$ & $\begin{array}{l}\text { Two feature } \\
\text { films based } \\
\text { on the } \\
\text { James } \\
\text { Heriot } \\
\text { novels } \\
\text { Prime time } \\
\text { Sunday } \\
\text { night TV } \\
\text { Series }\end{array}$ & $\begin{array}{l}1974- \\
1975\end{array}$ & $\begin{array}{l}\text { Thirsk is home to The World } \\
\text { of James Herriot, a visitor } \\
\text { attraction based at the home of } \\
\text { the infamous real-life vet, } \\
\text { attracting about } 45,000 \\
\text { visitors per year. The centre } \\
\text { also portrays sets from the TV } \\
\text { filming. }\end{array}$ \\
\hline $\begin{array}{l}\text { Kircudbright, } \\
\text { South West } \\
\text { Scotland }\end{array}$ & $\begin{array}{l}\text { The Wicker } \\
\text { Man }\end{array}$ & $\begin{array}{l}\text { Film } \\
\text { (cult horror/ } \\
\text { thriller) }\end{array}$ & 1972 & $\begin{array}{l}\text { Since } 2002 \text {, an annual } \\
\text { weekend festival based } \\
\text { loosely on the film has been } \\
\text { held in July. 'The Wickerman } \\
\text { Festival' offers cult music, } \\
\text { dance and art. In } 2006,16,000 \\
\text { attendees were recorded, from } \\
\text { a baseline of 5,000 in } 2002 \text {. }\end{array}$ \\
\hline
\end{tabular}

\footnotetext{
${ }^{1}$ Data extracted from the 2006 Visitor Attraction Monitor (VisitScotland)
} 
Table 2 Main Characteristics of Respondents who Visited 'Just to See Balamory' compared with other types of tourist

\begin{tabular}{|c|c|c|c|}
\hline & $\begin{array}{l}\text { Percentage of } \\
\text { respondents }\end{array}$ & $\begin{array}{l}\text { Pearson chi-square } \\
\text { value }\end{array}$ & p-value \\
\hline First time visit to Mull & 73.1 & 1.017 & 0.797 \\
\hline On a day trip from home & 46.4 & 10.528 & 0.104 \\
\hline Did not visit other places/attractions & 85.1 & $57.228 * *$ & 0.000 \\
\hline Visit more likely to be prompted by child & 74.6 & $33.958 * *$ & 0.000 \\
\hline Knew little about destination pre-visit & 40 & 11.516 & 0.242 \\
\hline More likely to follow film location trail & 84.6 & 6.192 & 0.103 \\
\hline Seeing coloured houses was highlight for kids & 92.3 & $20.835 *$ & 0.05 \\
\hline Expected more Balamory-related things to do & 83.1 & 18.476 & 0.102 \\
\hline Balamory theme not promoted enough & 10.8 & $24.417 * *$ & 0.018 \\
\hline Spent less time than expected at destination & 30.8 & 7.184 & 0.304 \\
\hline More likely to buy Balamory merchandise & 84.6 & $11.678 * *$ & 0.009 \\
\hline Felt less welcome in Tobermory & 11.1 & 18.989 & 0.08 \\
\hline Parent more likely to be disappointed with visit & 34.9 & 10.639 & 0.560 \\
\hline Less likely to return in future & 55.2 & 16.317 & 0.177 \\
\hline
\end{tabular}




\begin{tabular}{|c|c|c|c|}
\hline & $\begin{array}{l}\text { Percent of } \\
\text { respondents } \\
\text { stating agree or } \\
\text { strongly agree }\end{array}$ & Mean & St. Dev \\
\hline Seeing coloured houses was the highlight of the trip for the children & 89.5 & 1.65 & 0.838 \\
\hline There were lots of things to for children in Tobermory & 14.7 & 3.52 & 0.922 \\
\hline I felt that Tobermory was a safe environment for my children & 61.2 & 2.46 & 0.972 \\
\hline I expected there to be more Balamory-related things to do & 70 & 2.17 & 1.161 \\
\hline My children were disappointed by the trip to Balamory & 16.3 & 3.73 & 1.122 \\
\hline I was disappointed by the trip to Balamory & 28.7 & 3.41 & 1.283 \\
\hline We felt welcome in Tobermory & 75.8 & 2.13 & 0.863 \\
\hline We got good value for money & 55.4 & 2.53 & 0.954 \\
\hline I thought the Balamory theme was promoted too much & 11.6 & 3.89 & 0.924 \\
\hline The journey from the ferry took longer than I had expected & 24.6 & 3.60 & 1.193 \\
\hline
\end{tabular}

Mean scores on a scale of $1-5$, where $1=$ strongly agree and $5=$ strongly disagree 
Table 4 Film-Related and Destination-Related Components Liked and Disliked

\begin{tabular}{|l|l|l|l|}
\hline Film-Related Components & \multicolumn{2}{l|}{ Destination-Related Components } \\
\hline Adult's likes & & & \\
\hline Seeing children's enjoyment & $14.4 \%$ & Scenery/landscape & $26.2 \%$ \\
\hline Seeing coloured houses & $9.2 \%$ & Walking around Tobermory & $11.8 \%$ \\
\hline & & Beach & $7.2 \%$ \\
\hline Adult's dislikes & & & \\
\hline & & Transport on Island & $18.5 \%$ \\
\hline & & Cost & $16.4 \%$ \\
\hline & & Weather & $16.4 \%$ \\
\hline & & Lack of good facilities & $7.2 \%$ \\
\hline & & Lack of things to do & $6.2 \%$ \\
\hline Children's likes & & & \\
\hline Seeing coloured houses & $54.9 \%$ & Ferry journey & $5.6 \%$ \\
\hline Seeing Balamory village & $6.2 \%$ & & \\
\hline Visiting specific houses & $6.2 \%$ & & \\
\hline & & & \\
\hline Children's dislikes & & & $14.4 \%$ \\
\hline No Balamory characters & $12.8 \%$ & Weather & $12.3 \%$ \\
\hline & & Transport and journey & $7.2 \%$ \\
\hline & & Walking up hills & $5.6 \%$ \\
\hline & & Not much to do & \\
\hline
\end{tabular}




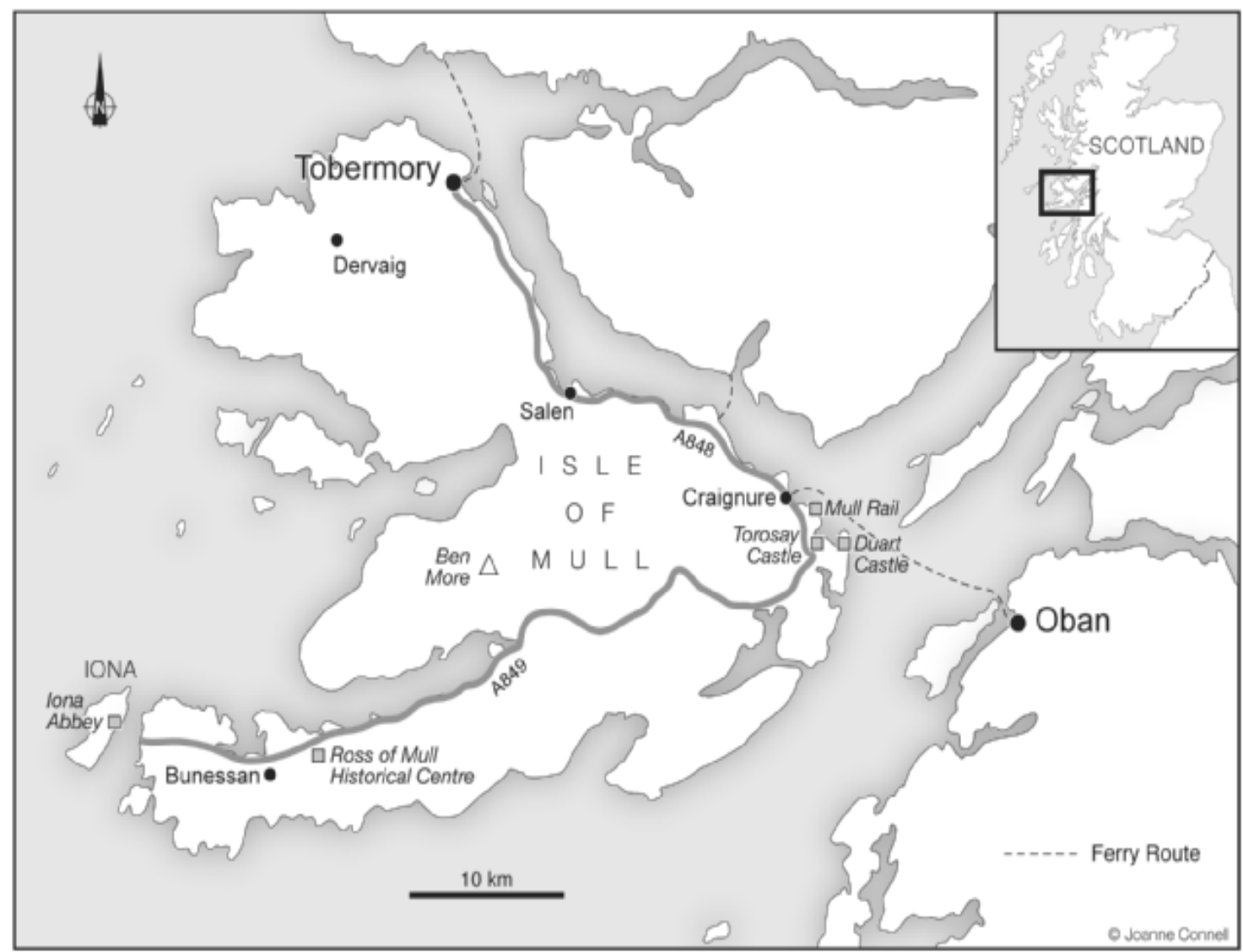

Figure 1 Location Map of the Isle of Mull 


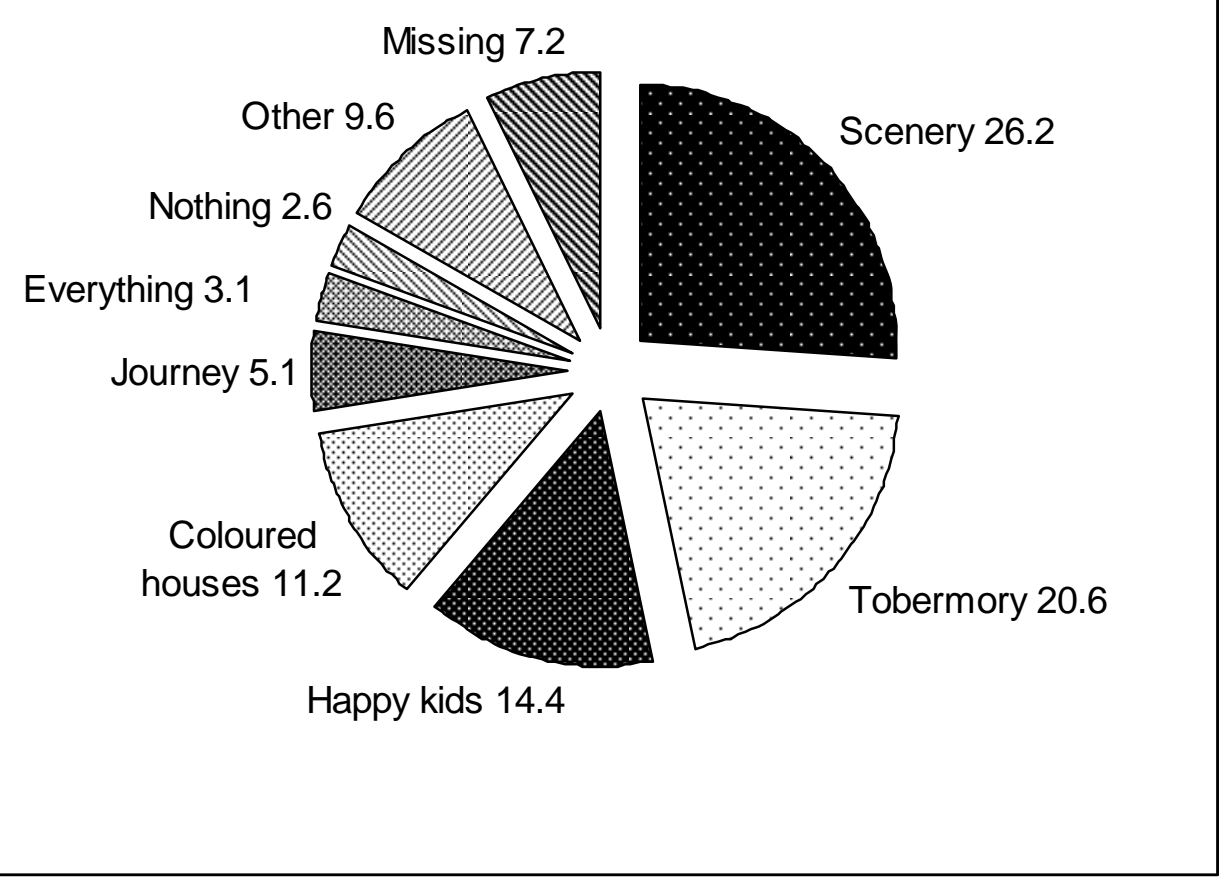

Figure 2 Features of the visit liked most by adults: percentage of respondents 


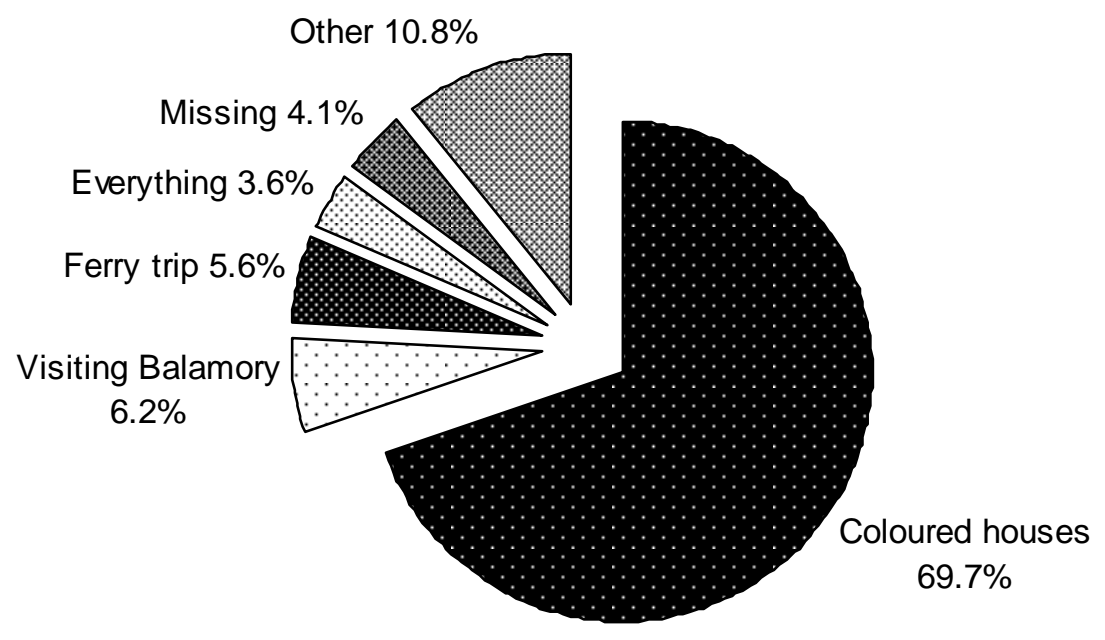

Figure 3 Features of the visit liked most by children: percentage of respondents 


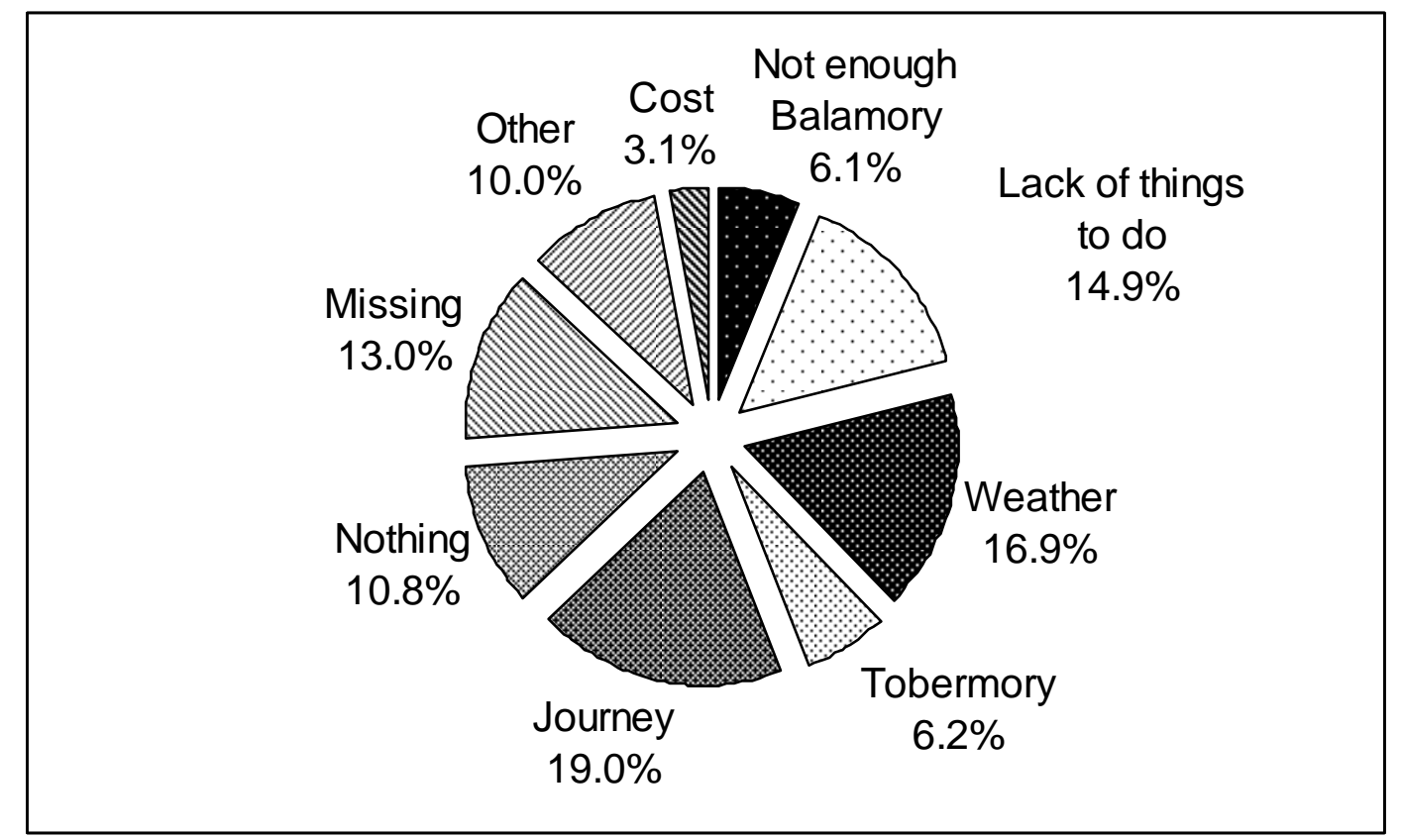

Figure 4 Features of the visit liked least by adults: percentage of respondents 


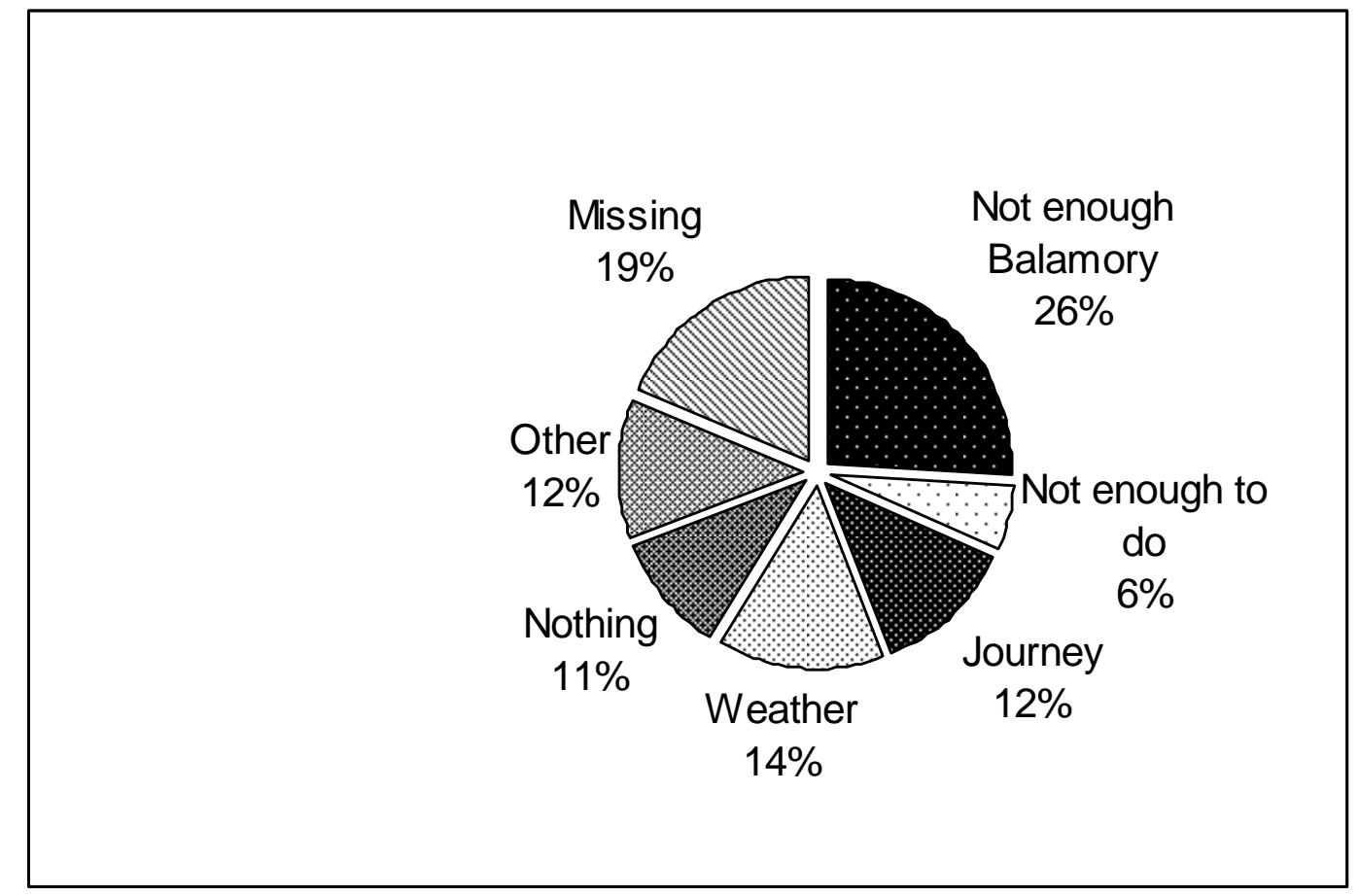

Figure 5 Features of the visit liked least by children: percentage of respondents 


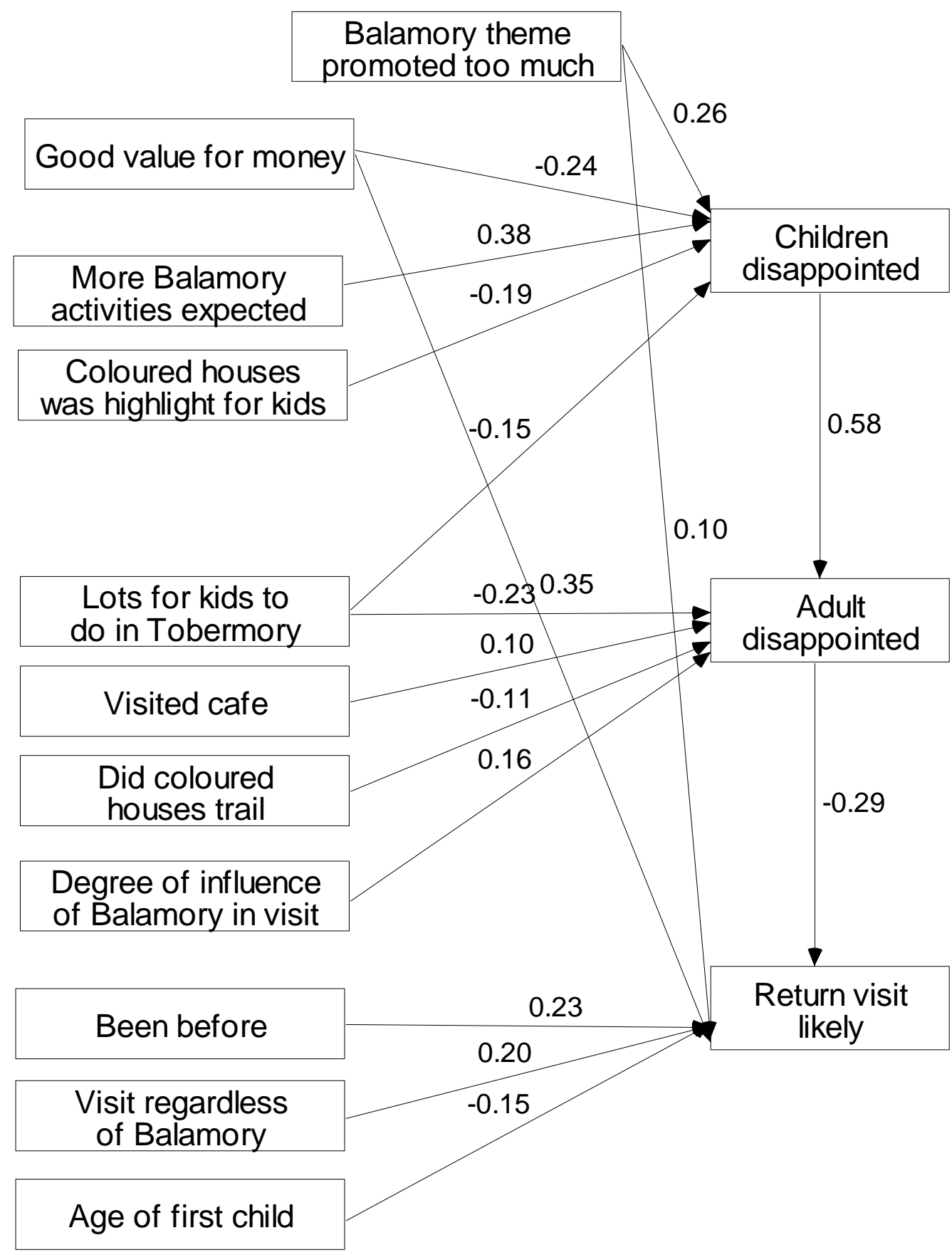

Figure 6 Model for the Likelihood of a Return Visit - Beta Coefficients shown at the centre-point of each link. $(\mathrm{CMIN} / \mathrm{DF}=1.649, \mathrm{CFI}=0.897, \mathrm{RMSEA}=0.058)$ 


\section{REFERENCES}

Argyll and the Isles Enterprise, Argyll, the Isles, Loch Lomond, Stirling and the Trossachs Tourist Board, Argyll and Bute Council, Scottish Tourist Board and Highlands and Islands Enterprise (2000) Mull Visitor Survey. Edinburgh: System Three.

Argyll, the Isles, Loch Lomond, Stirling and the Trossachs Tourist Board (2003) Toddler tourism takes off. Tourism News. Stirling: AILLSTTB, p1.

Boyle, B. (2003) The Holy Grail of Film Tourism - or - How to Increase Visitor Numbers Without Really Trying. In: D.V.L.Macleod (ed.) Niche Tourism in Question pp101-104. Glasgow: University of Glasgow Crichton Publications.

BBC Worldwide (2004) Balamory goes interactive with PC title from BBC Multimedia 21/1/04, press release.

BBC Worldwide (2005) BBC Worldwide Showcases the Latest Properties in its HighQuality Portfolio at L!censing International 31/5/05, press release.

Beeton, S. (2001) Smiling for the Camera: The Influence of Film Audiences on a Budget Tourism Destination. Tourism, Culture and Communication 3: 15-25.

Beeton, S. (2004) The More Things Change...A Legacy of Film-Induced Tourism. Proceedings of the International Tourism and Media Conference

Beeton, S. (2005) Film-Induced Tourism. Clevedon: Channel View Publications.

Bentler, P.M. (1990). Comparative Fit Indices in Structural Models. Psychological Bulletin, 107, 236-246.

Berger, J. (1972) Ways of Seeing. London: Penguin/BBC. 
Browne, M.W. and Cudeck, R. (1993). Alternative ways of assessing model fit. In K.A. Bollen and J.S. Long (eds) Testing Structural Equation Models. Newbury Park, CA: Sage, pp. 136-162.

Bruce, D. (1996) Scotland the Movie. Edinburgh: Polygon.

Busby, G. and Klug, J. (2001) Movie-induced Tourism: The Challenge of Measurement and Other Issues. Journal of Vacation Marketing 7: 316-332.

Butler, R. (1990) The Influence of the Media in Shaping International Tourist Patterns. Tourism Recreation Research 15: 46-53.

Butts, F.B. (1992) The Impacts of On-Location Filming of a Motion Picture on Tourists' Level of Enjoyment While Attending a Major Coastal Attraction. Journal of Hospitality and Leisure Marketing 1 (3): 31-39.

Byrne, B. M. (2001). Structural Equation Modeling with AMOS: Basic Concepts, Applications, and Programming. London: Lawrence Erlbaum.

Carl, D., Kindon, S. and Smith, K. (2007) Tourists' Experiences of Film Locations: New Zealand as 'Middle earth'. Tourism Geographies 9 (1): 49-63.

Chan, B. (2007) Film-induced Tourism in Asia: A Case Study of Korean TV Drama and Female Viewers' Motivation to Visit Korea. Tourism, Culture and Communication 7 (3): 207-224.

Connell, J. (2005a) Toddlers, Tourism and Tobermory: Destination Marketing Issues and TV-Induced Tourism. Tourism Management 26: 763-776.

Connell, J. (2005b) 'What's the Story in Balamory?': The Impacts of a Children's TV Programme on Small Tourism Enterprises on the Isle of Mull, Scotland. Journal of Sustainable Tourism 13: 228-255. 
Couldry, N. (1998) The View from Inside the 'Simulacrum': Visitors' Tales from the Set of Coronation Street. Leisure Studies 17: 94-107.

Couldry, N. (2005) On the Actual Street. In D.Crouch, R.Jackson and F.Thompson. (eds.), The Media and the Tourist Imagination. Converging Cultures, pp60-75. London: Routledge.

Crilly, R. (2003) Too many tiny tourists knocking on doors and clogging roads is Balamory story in Tobermory. The Herald, 23 October: p3.

Croy, G. and Walker, R.D. (2003) Rural Tourism and Film - Issues for Strategic Rural Development. In D. Hall, L. Roberts, and M. Mitchell. (eds.), New Directions in Rural Tourism, pp115-133. Aldershot: Ashgate.

Darrell, A.C. and Johnson, P.S. (2001) Repeat Visits to Attractions: A Preliminary Economic Analysis. Tourism Management 22 (2): 119-126

Davies, M.M. (2001) 'Dear BBC': Children, TV Storytelling and the Public Sphere. Cambridge: Cambridge University Press.

Davin, S. (2005) Tourists and TV Viewers: Some Similarities. In D.Crouch, R.Jackson and F.Thompson. eds., The Media and the Tourist Imagination. Converging Cultures, pp170-182. London: Routledge.

Dehany, M. (2003) Manager, Craignure Tourist Information Centre, personal communication.

Eco, U. (1986) Travels in Hyperreality. San Diego: Harcourt Brace Jovanovich.

Edensor, T. (2005) Mediating William Wallace: Audio-Visual technologies in Tourism. In The Media and the Tourist Imagination. Converging Cultures, D.Crouch, R.Jackson and F.Thompson. eds., pp105-118. London: Routledge. 
Escher, A. and Zimmerman, S. (2001) Geography Meets Hollywood: The Role of Landscape in Feature Films. Geographische Zeitschrift 89: 227-236.

Evans, M. (1997) Plugging into TV tourism. Insights March D35-38. London: English Tourist Board.

Featherstone, M. (1991) Consumer Culture and Postmodernism. London: Sage.

Feifer, M. (1985) Going Places. London: Macmillan.

Film Council (2007) Statistical Yearbook 2006/7. Chapter 10: Audiences.

http://rsu.ukfilmcouncil.org.uk $/$ pf $=\&$ low $=\& y=2006 \& c=10 \& s=$. Accessed10th February 2008.

Film Distributors Association (2005) Range and contrasts of UK film locations highlighted in regional critics poll as industry celebrates 50th FDA Cinema Days with biggest-ever event. Press release Thursday 29 September 2005. http://www.launchingfilms.com/journalists/index.php?name=29+September $+2005+-$ + Range + and + contrasts + of $+U K+$ film + locations + highlighted. Accessed on $17^{\text {th }}$ January 2007.

Gitelson, R.J. and Crompton, J.L. (1984) Insights into the Repeat Vacation Phenomenon. Annals of Tourism Research 11 (2): 199-217.

Hills M. (2002) Fan Cultures. London: Routledge.

Hudson, S. and Ritchie, J.R.B. (2006a) Promoting Destinations via Film Tourism: An Empirical Identification of Supporting Marketing Initiatives. Journal of Travel Research 44: 387-396.

Hudson, S. and Ritchie, J.R.B. (2006b) Film Tourism and Destination Marketing: The Case of Captain Corelli's Mandolin. Journal of Vacation Marketing 12 (3): 256-268. 
Hydra Associates (1997) Scotland on Screen -The Development of the Film and TV Industry in Scotland. Scottish Enterprise and Highlands and Islands Enterprise.

James, A., Jenks, C. and Prout, A. (1998) Theorizing Childhood. London: Falmer Press.

Jobber, D. (2006) Principles and Practice of Marketing. Maidenhead: McGraw-Hill, $5^{\text {th }}$ edition.

Jones, D. and Smith, K. (2005) Middle-earth Meets New Zealand: Authenticity and Location in the Making of The Lord of the Rings. Journal of Management Studies 42 (5): 923-945.

Kelbie, P. (2005) Toddlers, TV and a Tourism Crisis for Tobermory: The End of a Highland Fling. The Independent, 30 April: p12.

Kim, S.S., Agrusa, J., Lee. H. and Chon, K. (2007) Effects of Korean TV Dramas on the Flow of Japanese Tourists. Tourism Mnagement 28 (5): 1340-1353.

Kim, H. and Richardson, S. (2003) Motion Picture Impacts on Destination Images. Annals of Tourism Research 30: 216-237.

Kotler, P. and Armstrong, G. (2007) Principles of Marketing. Harlow: Prentice Hall. $12^{\text {th }}$ edition.

Kozak, M. (2001) Repeaters' Behavior at Two Distinct Destinations. Annals of Tourism Research 28 (3): 784-807.

Lennon, J.J. (2001) (ed.) Tourism Statistics: International Perspectives and Current Issues. London: Continuum.

Macgregor, F. (2003) Kid's Show to Wave Tourism Magic Wand. The Scotsman, December $30^{\text {th }}$. 
Macionis, N. (2004) Understanding the Film-Induced Tourist. In: W. Frost, W.G.

Croy and S. Beeton. eds., Proceedings of the International Tourism and Media

Conference Melbourne, Australia: Tourism Research Unit, Monash University, pp8697.

Macionis, N. and Sparks, B. (2006) Film Induced Tourism: An Incidental Experience. International Tourism and Media Conference, Melbourne, Australia.

Mintel (2003) Film Tourism - International. October 2003. London: Mintel International Group Limited.

Mordue, T. (2001) Performing and Directing Resident/Tourist Cultures in Heartbeat Country. Tourist Studies 1: 233-252.

Morgan, N. and Pritchard, A. (1998) Tourism Promotion and Power: Creating Images, Creating Identities. Chichester: Wiley.

Nickerson, N.P. and Jurowski, C. (2001) The Influence of Children on Vacation Patterns, Journal of Vacation Marketing 7: 19-30.

Olsberg|SPI (2007) How Film and TV Programmes Promote Tourism in the UK, London: Film Council.

O’Neill, K., Butts, S. and Busby, G. (2005) The Corellification of Cephallonian Tourism. Anatolia 16 (2): 207-226.

Oppermann, M. (1998) Destination Threshold Potential and the Law of Repeat Visitation. Journal of Travel Research 37 (1): 131-137.

Oxford Economic Forecasting (2005) The Economic Contribution of the UK Film Industry, Oxford: OEF. 
Pendreigh, B. (2002) The Pocket Scottish Movie Book. Edinburgh: Mainstream Publishing.

Pocock, D. (1992) Catherine Cookson Country: Tourist Expectation and Experience. Geography 77: 236-243.

Pretes, M. (1995) Postmodern Tourism: The Santa Claus Industry. Annals of Tourism Research 22: 1-15.

Reid, M. (2004) Why Can't we Take Pride in the Tobermory Tourist Trap? The Herald, 30 March: p14.

Riley, R. and Van Doren, C. (1992) Movies as Tourism Promotion: A Push Factor in a Pull Location. Tourism Management 13: 267-274.

Riley, R., Baker, D. and Van Doren, C. (1998) Movie-induced tourism. Annals of Tourism Research 25: 919-935.

Ritchie, J. R. B. and Crouch, G. I. (2003) The Competitive Destination: A Sustainable Tourism Perspective. Wallingford: CABI.

Ross, P. (2004) Fantasy Island. Sunday Herald, 19 December.

Ryan, C. (ed). (2002) The Tourist Experience. London: Continuum, 2nd edition,

Scottish Screen (2007a) Scotland. The Creative Country. Glasgow: Scottish Screen.

Scottish Screen (2007b) Made in Scotland. Glasgow: Scottish Screen.

Seenan, G. (2004) Mulled Whine Over Toddler Tourism. 29 March: p9.

Singh, K. and Best, G. (2004) Film-Induced Tourism: Motivations of Visitors to the Hobbiton Movie Set as Featured in The Lord of the Rings. In: W. Frost, W.G. Croy 
and S. Beeton. eds., Proceedings of the International Tourism and Media Conference Melbourne, Australia: Tourism Research Unit, Monash University, pp98-111.

Squire, S. (1994) Gender and Tourist Experiences; Assessing Women's Shared Meanings for Beatrix Potter. Leisure Studies 13: 195-209.

Tak-Kee, H. and Wan, D. (2006) Predictive Model for Repeat Visitors to Singapore. Advances in Hospitality and Leisure 2: 107-121

Thornton, P.R., Shaw, G. and Williams, A.M. (1997) Tourist Group Holiday Decision-Making and Behaviour: The Influence of Children. Tourism Management 18: 287-297.

Tooke, N. and Baker, M. (1996) Seeing is Believing: The Effect of Film on Visitor Numbers to Screened Locations. Tourism Management 17: 87-94.

Tzanelli, R. (2004) Constructing the 'Cinematic Tourist': The Sign Industry of the Lord of the Rings. Tourist Studies 4 (1): 21-42.

Urry, J. (1990) The Tourist Gaze. London: Sage

Warnick, R.B., Bojanic, D.C. and Siriangkul, A. (2005) Movie Effects on the Image of Thailand Among College Student Travelers. In: J.G. Peden and R. Schuster. eds., Proceedings of the 2005 Northeastern Recreation Research Symposium, April 10-12. Bolton Landing, N.Y: U.S. Forest Service.

Wheaton, B., Muthen, B., Alwin, D.F. \& Summers, G.F. (1977) Assessing Reliability and Stability in Panel Models. In: D.R. Heise. ed., Sociological Methodology 1977. San Francisco: Jossey-Bass, p84. 